\title{
Whiteness Scholarship in the Counseling Profession: A 35-Year Content Analysis
}

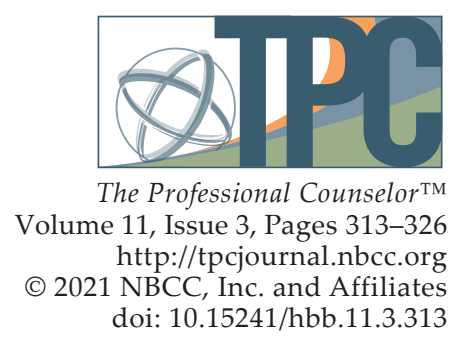

Hannah B. Bayne, Danica G. Hays, Luke Harness, Brianna Kane

We conducted a content analysis of counseling scholarship related to Whiteness for articles published in national peer-reviewed counseling journals within the 35-year time frame (1984-2019) following the publication of Janet Helms's seminal work on White racial identity. We identified articles within eight counseling journals for a final sample of 63 articles - eight qualitative (12.7\%), 38 quantitative $(60.3 \%)$, and 17 theoretical $(27.0 \%)$. Our findings outline publication characteristics and trends and present themes for key findings in this area of scholarship. They reveal patterns such as type of research methodology, sampling, correlations between White racial identity and other constructs, and limitations of White racial identity assessment. Based on this overview of extant research on Whiteness, our recommendations include future research that focuses on behavioral and clinical manifestations, anti-racism training within counselor education, and developing a better overall understanding of how White attitudes and behaviors function for self-protection.

Keywords: Whiteness, White racial identity, counseling scholarship, counseling journals, content analysis

Counselors are ethically guided to understand and address the roles that race, privilege, and oppression play in impacting both themselves and their clients (American Counseling Association [ACA], 2014). Most practitioners identify as White despite the population diversity in the United States (U.S. Census Bureau, 2020), which holds implications for understanding how Whiteness impacts culturally competent counselor training and practice (Helms, 1984, 1995, 2017). It is important, then, to understand the role of racial identity within counseling, particularly in terms of how Whiteness can be deconstructed and examined as a constant force impacting power dynamics and client progress (Helms, 1990, 2017; Malott et al., 2015). Whiteness models (i.e., Helms, 1984) describe how White people make meaning of their own and others' racial identity as a result of personal and social experiences with race (Helms, 1984, 2017). The Helms model, along with other constructs, such as color-blindness (Frankenberg, 1993), White racial consciousness (Claney \& Parker, 1989), and White fragility (DiAngelo, 2018), implicates the harmful impacts of Whiteness and invites critical reflection of how these constructs impact the counseling process.

Though much has been theorized regarding Whiteness and its impact within the helping professions, the contributions of Whiteness scholarship within professional counseling journals are unclear. An understanding of the specific professional applications and explorations of Whiteness within counseling can help identify best practices in counselor education, research, and practice to counter the harmful impacts of Whiteness and encourage growth toward anti-racist attitudes and behaviors.

\section{White Racial Identity and Related Constructs}

The Helms (1984) model of White racial identity (WRI) presents Whiteness as a developmental process centering on racial consciousness (i.e., the awareness of one's own race), as well as awareness of attitudes

The authors would like to thank Cheolwoo Park for his invaluable assistance in this study. Hannah B. Bayne, PhD, LMHC (FL), LPC (VA), is an assistant professor at the University of Florida. Danica G. Hays, PhD, is a dean and professor at the University of Nevada Las Vegas. Luke Harness is a doctoral student at the University of Florida. Brianna Kane is a doctoral student at the University of Florida. Harness and Kane contributed equally to the project and share third authorship. Correspondence may be addressed to Hannah B. Bayne, 140 Norman Hall, Gainesville, FL 32611, hbayne@coe.ufl.edu. 
and behaviors toward other racial groups (Helms, 1984, 1990, 1995, 2017). According to Helms, White people have the privilege to restrict themselves to environments and relationships that are homogenous and White-normative, thus limiting their progression through the stages (DiAngelo, 2018; Helms, 1984). The initial model (Helms, 1984) contained five stages (i.e., Contact, Disintegration, Reintegration, Pseudo-Independence, and Autonomy), each with a positive or negative response that could facilitate progression toward a more advanced stage, regression to earlier stages of the model, or stagnation at the current stage of development. Helms (1990) later added a sixth status, Immersion/Emersion, to the model as an intermediary between Pseudo-Independence and Autonomy. These final three stages of the model (i.e., Pseudo-Independence, Immersion/Emersion, Autonomy) involve increasing levels of racial acceptance and intellectual and emotional comfort with racial issues, which in turn leads to the development of a positive and anti-racist WRI (Helms, 1990, 1995).WRI requires intentional and sustained attention toward how Whiteness impacts the self and others, with progression through the stages leading to beneficial intra and interpersonal outcomes (Helms, 1990, 1995, 2017).

Since Helms (1984), several additional components of Whiteness have been introduced, primarily within psychology, counseling psychology, and sociology scholarship. White racial consciousness is distinct from the WRI model in its focus on attitudes toward racial out-groups, rather than using the White in-group as a reference point (Choney \& Behrens, 1996; Claney \& Parker, 1989). Race essentialism refers to the degree to which a person believes that race reflects biological differences that influence personal characteristics (Tawa, 2017). Symbolic/modern racism refers to overt attitudes of White people related to their perceived superiority (Henry \& Sears, 2002; McConahay, 1986). A fourth Whiteness component, color-blind racial ideology, enables color-evasion (i.e., "I don't see color") and power-evasion roles (i.e., "everyone has an equal chance to succeed"), which allow White people to deny the impact of race and therefore evade a sense of responsibility for oppression (Frankenberg, 1993; Neville et al., 2013). White privilege refers to the systemic and unearned advantages provided to White people over people of color (McIntosh, 1988). There are also psychosocial costs accrued to White people as a result of racism that include (a) affective (e.g., anxiety and fear, anger, sadness, guilt and shame); (b) cognitive (i.e., distorted views of self, others, and reality in general related to race); and (c) behavioral (i.e., avoidance of cross-racial situations or loss of relationships with White people) impacts (Spanierman \& Heppner, 2004). White fragility (DiAngelo, 2018) reflects defensive strategies White people use to reestablish cognitive and affective equilibrium regarding their own Whiteness and impact on others.

Whiteness concepts are thus varied, with different vantage points of how White people might engage in the consideration of power, privilege, and racism, and what potential implications these constructs might have on their development. These constructs also seem largely rooted in psychology research, and it is therefore unclear the extent to which counselor educators and researchers have examined and applied these constructs to training and practice. Such an analysis can assist in situating Whiteness within the specific contexts and professional roles of counseling and can identify areas in need of further study.

\section{The Present Study}

Because of the varied components of Whiteness, as well as its potential impact on counselor development and counseling process and outcome (Helms, 1995, 2017), there is a need to examine how these constructs have been examined and applied within counseling research. We sought to identify how and to what degree Whiteness constructs have been explored or developed within the counseling 
profession since the publication of the Helms (1984) model. We hope to summarize empirical and theoretical constructs related to Whiteness in national peer-reviewed counseling journals to more clearly consider implications for training and practice. Such analysis can highlight the saliency of WRI, demonstrating the need for continued focus on the influences and impacts of Whiteness within counseling. The following research questions were addressed: 1 ) What types of articles, topics, and major findings are published on Whiteness?; 2) What are the methodological features of articles published on Whiteness?; and 3) What are themes from key findings across these publications?

\section{Method}

We employed content analysis to identify publication patterns of national peer-reviewed counseling journals regarding counseling research on Whiteness in order to understand the scope and depth of this scholarship as it applies to fostering counselor training and practice. Content analysis is the systematic review of text in order to produce and summarize numerical data and identify patterns across data sources regarding phenomena (Neuendorf, 2017). In addition, content analysis has been used to summarize and identify patterns for specific topics, including multicultural counseling (e.g., Singh \& Shelton, 2011).

\section{Data Sources and Procedure}

The sampling units for this study were journal articles on Whiteness topics published in national peer-reviewed journals $(N=24)$ of the ACA and its divisions, the American School Counselor Association, the American Mental Health Counselors Association, the National Board for Certified Counselors, and Chi Sigma Iota International. We used the following search terms: White supremacy, White racial identity, White privilege, White fragility, White guilt, White shame, White savior, White victimhood, color-blindness, race essentialism, anti-racism, White racism, reverse racism, White resistance, and Whiteness. We selected a 35-year review period (i.e., 1984-2019) to correspond with Helms's (1984) foundational work on WRI.

We reviewed article abstracts to identify an initial sampling unit pool ( $N=185$ articles; 29 qualitative [15.6\%], 56 quantitative [30.3\%], and 100 theoretical [54.1\%]). In pairs, we reviewed the initial pool to more closely examine each sampling unit for inclusion in analysis. We excluded 122 articles upon closer inspection (e.g., special issue introductions, personal narratives or profiles, broader focus on social justice issues, ethnic identity, multiculturalism, or primary focus on another racial group). This resulted in a final sample of 63 articles - eight qualitative (12.7\%), 38 quantitative $(60.3 \%)$, and 17 theoretical $(27.0 \%$; see Table 1$)$.

\section{Research Team}

Our team consisted of four researchers: two counselor education faculty members and two counselor education doctoral students. We all identify as White. Hannah B. Bayne and Danica G. Hays hold doctorates in counselor education, and Luke Harness and Brianna Kane hold master's degrees in school counseling and mental health counseling, respectively. We were all trained in qualitative research methods, and Bayne and Hays have conducted numerous qualitative research projects, including previous content analyses. Bayne and Hays trained Harness and Kane on content analysis through establishing coding protocols and coding together until an acceptable inter-rater threshold was met. 
Table 1

Exclusion and Inclusion of Articles by Journal and Article Type

\begin{tabular}{|c|c|c|c|c|c|c|c|c|}
\hline \multirow{2}{*}{ Journal } & \multicolumn{3}{|c|}{ Excluded $^{a}$} & \multicolumn{3}{|c|}{ Included } & \multirow{2}{*}{$\begin{array}{c}\text { Total } \\
\text { Sample }\end{array}$} & \multirow{2}{*}{$\begin{array}{c}\% \text { of } \\
\text { Final } \\
\text { Sample }\end{array}$} \\
\hline & Quant & Qual & Theory & Quant & Qual & Theory & & \\
\hline Journal of Counseling $\mathcal{E}$ Development & 5 & 0 & 11 & 16 & 4 & 5 & 24 & $38.1 \%$ \\
\hline $\begin{array}{l}\text { Journal of Multicultural Counseling and } \\
\text { Development }\end{array}$ & 3 & 3 & 14 & 14 & 3 & 8 & 24 & $38.1 \%$ \\
\hline Counselor Education and Supervision & 1 & 0 & 1 & 4 & 1 & 2 & 7 & $11.1 \%$ \\
\hline The Journal of Humanistic Counseling & 1 & 2 & 14 & 1 & 1 & 1 & 3 & $4.8 \%$ \\
\hline Journal of Mental Health Counseling & 0 & 0 & 2 & 1 & 0 & 3 & 2 & $3.2 \%$ \\
\hline Counseling and Values & 0 & 0 & 0 & 1 & 0 & 0 & 1 & $1.6 \%$ \\
\hline The Family Journal & 1 & 1 & 5 & 0 & 0 & 2 & 1 & $1.6 \%$ \\
\hline Journal of Creativity in Mental Health & 0 & 2 & 4 & 0 & 0 & 1 & 1 & $1.6 \%$ \\
\hline Adultspan Journal & 0 & 0 & 0 & 0 & 0 & 0 & 0 & $0 \%$ \\
\hline The Career Development Quarterly & 0 & 0 & 0 & 0 & 0 & 0 & 0 & $0 \%$ \\
\hline $\begin{array}{l}\text { Counseling Outcome Research } \\
\text { and Evaluation }\end{array}$ & 0 & 2 & 0 & 0 & 0 & 0 & 0 & $0 \%$ \\
\hline $\begin{array}{l}\text { Journal for Social Action in Counseling } \\
\quad \text { and Psychology }\end{array}$ & 0 & 0 & 3 & 0 & 0 & 0 & 0 & $0 \%$ \\
\hline The Journal for Specialists in Group Work & 0 & 1 & 6 & 0 & 0 & 0 & 0 & $0 \%$ \\
\hline $\begin{array}{l}\text { Journal of Addictions \& Offender } \\
\text { Counseling }\end{array}$ & 0 & 0 & 0 & 0 & 0 & 0 & 0 & $0 \%$ \\
\hline Journal of Child and Adolescent Counseling & 0 & 0 & 0 & 0 & 0 & 0 & 0 & $0 \%$ \\
\hline Journal of College Counseling & 2 & 0 & 0 & 0 & 0 & 0 & 0 & $0 \%$ \\
\hline $\begin{array}{l}\text { Journal of Counselor Leadership } \\
\text { and Advocacy }\end{array}$ & 1 & 5 & 6 & 0 & 0 & 0 & 0 & $0 \%$ \\
\hline Journal of Employment Counseling & 2 & 0 & 4 & 0 & 0 & 0 & 0 & $0 \%$ \\
\hline Journal of LGBTQ Issues in Counseling & 0 & 1 & 2 & 0 & 0 & 0 & 0 & $0 \%$ \\
\hline $\begin{array}{l}\text { Journal of Military and Government } \\
\text { Counseling }\end{array}$ & 0 & 0 & 0 & 0 & 0 & 0 & 0 & $0 \%$ \\
\hline $\begin{array}{l}\text { Measurement and Evaluation in } \\
\text { Counseling and Development }\end{array}$ & 1 & 0 & 2 & 0 & 0 & 0 & 0 & $0 \%$ \\
\hline Professional School Counseling & 0 & 0 & 2 & 0 & 0 & 0 & 0 & $0 \%$ \\
\hline Rehabilitation Counseling Bulletin & 3 & 1 & 2 & 0 & 0 & 0 & 0 & $0 \%$ \\
\hline The Professional Counselor & 0 & 1 & 0 & 0 & 0 & 0 & 0 & $0 \%$ \\
\hline Professional School Counseling & 0 & 0 & 2 & 0 & 0 & 0 & 0 & $0 \%$ \\
\hline
\end{tabular}

Note . Quant = quantitative research articles; Qual = qualitative research articles; Theory $=$ theoretical articles.

${ }^{a}$ Articles were excluded from analysis if they did not directly address Whiteness or White racial identity (e.g., special issue introductions, personal narratives or profiles, broader focus on social justice issues, ethnic identity, multiculturalism, or primary focus on another racial group). 


\section{Coding Frame Development}

Dimensions and categories for our coding frame included: journal outlet, publication year, author characteristics (i.e., name, institutional affiliation, ACES region), article type, sample characteristics (e.g., composition, size, gender, race/ethnicity), research components (e.g., research design, data sources or instrumentation, statistical methods, research traditions, trustworthiness strategies), topics discussed (e.g., WRI attitudes, counselor preparation models, intervention use, client outcomes, counseling process), article implications and limitations, and a brief statement of key findings. Over the course of research team meetings, we reviewed and operationalized the coding frame dimensions and categories. We then selected one empirical and one conceptual article to code together in order to refine the coding frame, which resulted in further clarification of some categories.

\section{Data Analysis}

To establish evidence of replicability (Neuendorf, 2017), we coded eight (12.7\%) randomly selected cases proportionate to the sample composition (i.e., two conceptual, four quantitative, two qualitative). We analyzed the accuracy rate of coding using $\mathrm{R}$ data analysis software for statistical analysis (LoMartire, 2020). Across 376 possible observations for eight cases, there was an acceptable rate of coding accuracy (0.89). In addition, pairwise Pearson-product correlations among raters indicated that coding misses did not follow a systematic pattern for any variable ( $r=-.10$ to .65$)$, and thus there were no significant variations in coding among research team members. After pilot coding, we met to discuss areas of coding misses to ensure understanding of the final coding frame.

For the main coding phase, we worked in pairs and divided the sample equally for independent and consensus coding. Upon completion of consensus coding of the entire sample, we extracted 29 keywords describing the Whiteness topics discussed in the articles. Bayne and Hays reviewed the 29 independent topics and collapsed the topics into eight larger themes. To identify themes across the key findings, Bayne and Harness reviewed 125 independent statements based on coder summaries of article findings, and through independent and consensus coding collapsed statements to yield three main themes.

\section{Results}

\section{Article Characteristics}

We focused on several article characteristics (Research Question 1): article type (conceptual, quantitative, qualitative); number of relevant articles per journal outlet; the relationship between journal outlet and article type; and frequency of Whiteness topics within and across journal outlets. Of the 24 national peer-reviewed counseling journals, eight journals (33.3\%) contained publications that met inclusion criteria (i.e., contained keywords for Whiteness from our search criteria and focused specifically on WRI). The number of publications in those journals ranged from 1 to 24 $(M=2.5 ; M d n=7.88 ; S D=10.15)$ and are listed in order of frequency in Table 2). There was not a significant relationship between the journal outlet and article type (i.e., quantitative, qualitative, conceptual) for this topic $(r=0.04, p=.39)$. 


\section{Table 2}

Articles Addressing Whiteness and Associated Keywords in National Peer-Reviewed Counseling Journals

\begin{tabular}{|c|c|c|}
\hline Journal & Articles Addressing Whiteness & Percent of Total Sample \\
\hline Journal of Counseling $\mathcal{E}$ Development & 24 & $38.1 \%$ \\
\hline Journal of Multicultural Counseling and Development & 24 & $38.1 \%$ \\
\hline Counselor Education and Supervision & 7 & $11.1 \%$ \\
\hline The Journal of Humanistic Counseling & 3 & $4.8 \%$ \\
\hline Journal of Mental Health Counseling & 2 & $3.2 \%$ \\
\hline Counseling and Values & 1 & $1.6 \%$ \\
\hline The Family Journal & 1 & $1.6 \%$ \\
\hline Journal of Creativity in Mental Health & 1 & $1.6 \%$ \\
\hline Adultspan Journal & 0 & $0 \%$ \\
\hline The Career Development Quarterly & 0 & $0 \%$ \\
\hline Counseling Outcome Research and Evaluation & 0 & $0 \%$ \\
\hline Journal for Social Action in Counseling and Psychology & 0 & $0 \%$ \\
\hline The Journal for Specialists in Group Work & 0 & $0 \%$ \\
\hline Journal of Addictions \& Offender Counseling & 0 & $0 \%$ \\
\hline Journal of Child and Adolescent Counseling & 0 & $0 \%$ \\
\hline Journal of College Counseling & 0 & $0 \%$ \\
\hline Journal of Counselor Leadership and Advocacy & 0 & $0 \%$ \\
\hline Journal of Employment Counseling & 0 & $0 \%$ \\
\hline Journal of LGBTQ Issues in Counseling & 0 & $0 \%$ \\
\hline Journal of Military and Government Counseling & 0 & $0 \%$ \\
\hline $\begin{array}{l}\text { Measurement and Evaluation in Counseling and } \\
\text { Development }\end{array}$ & 0 & $0 \%$ \\
\hline Professional School Counseling & 0 & $0 \%$ \\
\hline Rehabilitation Counseling Bulletin & 0 & $0 \%$ \\
\hline The Professional Counselor & 0 & $0 \%$ \\
\hline Professional School Counseling & 0 & $0 \%$ \\
\hline
\end{tabular}

Additionally, we identified eight themes of topics discussed within counseling research on Whiteness (see Table 3). For qualitative research, the three most frequently addressed topics were theory development, intrapsychic variables, and multicultural counseling competency (MCC). The most frequent topics discussed in theoretical articles were theory development, counselor preparation, Whiteness and WRI expression, cultural identity development, and counseling process. 


\section{Table 3}

Themes in Topics Discussed Within Whiteness and WRI Articles

\begin{tabular}{|c|c|c|c|c|c|c|}
\hline Theme & Description & $\begin{array}{l}N \\
\%\end{array}$ & $\begin{array}{l}\text { Quant } \\
n / \%\end{array}$ & $\begin{array}{l}\text { Qual } \\
n / \%\end{array}$ & $\begin{array}{c}\text { Theory } \\
n / \%\end{array}$ & Examples \\
\hline $\begin{array}{l}\text { Whiteness and } \\
\text { WRI Expression }\end{array}$ & $\begin{array}{l}\text { Attitudes and knowledge } \\
\text { related to WRI and } \\
\text { Whiteness constructs, with } \\
\text { some }(n=5) \text { examining } \\
\text { pre-posttest changes }\end{array}$ & $\begin{array}{c}43 \\
68.3 \%\end{array}$ & $\begin{array}{c}32 \\
74.4 \%\end{array}$ & $\begin{array}{c}3 \\
7.0 \%\end{array}$ & $\begin{array}{c}8 \\
18.6 \%\end{array}$ & $\begin{array}{l}\text { WRI attitudes, color-blind racial } \\
\text { attitudes, racism and responses, } \\
\text { White privilege and responses, and } \\
\text { developmental considerations }\end{array}$ \\
\hline $\begin{array}{c}\text { Cultural } \\
\text { Identity } \\
\text { Development }\end{array}$ & $\begin{array}{l}\text { Cultural identities and } \\
\text { developmental processes } \\
\text { outside of race }\end{array}$ & $\begin{array}{c}27 \\
42.9 \%\end{array}$ & $\begin{array}{c}21 \\
77.8 \%\end{array}$ & $\begin{array}{c}1 \\
3.7 \%\end{array}$ & $\begin{array}{c}5 \\
18.5 \%\end{array}$ & $\begin{array}{l}\text { Ethnic identity, womanist identity, } \\
\text { cultural demographics such as } \\
\text { gender and age }\end{array}$ \\
\hline $\begin{array}{l}\text { Counselor } \\
\text { Preparation }\end{array}$ & $\begin{array}{l}\text { Training implications, } \\
\text { with some presenting } \\
\text { training intervention } \\
\quad \text { findings }(n=6)\end{array}$ & $\begin{array}{c}23 \\
36.5 \%\end{array}$ & $\begin{array}{c}17 \\
73.9 \%\end{array}$ & $\begin{array}{c}1 \\
4.3 \%\end{array}$ & $\begin{array}{c}5 \\
21.8 \%\end{array}$ & $\begin{array}{c}\text { Pedagogy, training interventions, } \\
\text { and supervision process and } \\
\text { outcome }\end{array}$ \\
\hline $\begin{array}{c}\text { Theory } \\
\text { Development }\end{array}$ & $\begin{array}{l}\text { Development or } \\
\text { expansion of theoretical } \\
\text { concepts }\end{array}$ & $\begin{array}{c}18 \\
28.6 \%\end{array}$ & $\begin{array}{c}5 \\
27.8 \%\end{array}$ & $\begin{array}{c}5 \\
27.8 \%\end{array}$ & $\begin{array}{c}8 \\
44.4 \%\end{array}$ & $\begin{array}{l}\text { White racial consciousness versus } \\
\text { WRI, prominent responses to White } \\
\text { privilege, psychological dispositions } \\
\text { of White racism }\end{array}$ \\
\hline $\begin{array}{l}\text { Multicultural } \\
\text { Counseling } \\
\text { Competency }\end{array}$ & $\begin{array}{l}\text { Measurements of } \\
\text { perceived multicultural } \\
\text { counseling competency }\end{array}$ & $\begin{array}{c}12 \\
19.0 \%\end{array}$ & $\begin{array}{c}10 \\
83.3 \%\end{array}$ & $\begin{array}{c}2 \\
16.7 \%\end{array}$ & $\begin{array}{c}0 \\
0.0 \%\end{array}$ & $\begin{array}{l}\text { Perceived competency, } \\
\text { link with WRI }\end{array}$ \\
\hline $\begin{array}{l}\text { Counseling } \\
\text { Process }\end{array}$ & $\begin{array}{l}\text { Counseling process and } \\
\text { outcome variables }\end{array}$ & $\begin{array}{c}11 \\
17.5 \%\end{array}$ & $\begin{array}{c}8 \\
72.7 \%\end{array}$ & $\begin{array}{c}1 \\
9.1 \%\end{array}$ & $\begin{array}{c}2 \\
18.2 \%\end{array}$ & $\begin{array}{l}\text { Client perceptions, working alliance, } \\
\text { and clinical applications }\end{array}$ \\
\hline $\begin{array}{l}\text { Intrapsychic } \\
\text { Variables }\end{array}$ & $\begin{array}{l}\text { Affective and cognitive } \\
\text { components that influence } \\
\text { Whiteness and WRI }\end{array}$ & $\begin{array}{c}11 \\
17.5 \%\end{array}$ & $\begin{array}{c}8 \\
72.7 \%\end{array}$ & $\begin{array}{c}2 \\
18.2 \%\end{array}$ & $\begin{array}{c}1 \\
9.1 \%\end{array}$ & $\begin{array}{l}\text { Personality variables, cognitive } \\
\text { development, ego development }\end{array}$ \\
\hline $\begin{array}{c}\text { Assessment } \\
\text { Characteristics }\end{array}$ & $\begin{array}{l}\text { Development and/or } \\
\text { critique of Whiteness and } \\
\text { WRI measurements }\end{array}$ & $\begin{array}{c}9 \\
14.3 \%\end{array}$ & $\begin{array}{c}8 \\
88.9 \%\end{array}$ & $\begin{array}{c}0 \\
0.0 \%\end{array}$ & $\begin{array}{c}1 \\
11.1 \%\end{array}$ & $\begin{array}{l}\text { Limitations of WRI scales, } \\
\text { development of White privilege } \\
\text { awareness scales }\end{array}$ \\
\hline Total $^{\mathrm{a}}$ & & 154 & $\begin{array}{c}111 \\
72.1 \%\end{array}$ & $\begin{array}{c}15 \\
9.7 \%\end{array}$ & $\begin{array}{c}30 \\
19.5 \%\end{array}$ & \\
\hline
\end{tabular}

Note . Quant $=$ quantitative research articles; Qual = qualitative research articles; Theory $=$ theoretical articles. aPercentage total exceeds $100 \%$ because of rounding and/or topic overlap between articles.

\section{Methodological Features}

To address Research Question 2, we explored the methodological features of articles. These features included sample composition, research design, data sources, and limitations as reported within each empirical article $(n=46)$. 


\section{Sample Composition}

For the 45 studies providing information about the racial/ethnic composition of their samples, White individuals accounted for a mean of $91 \%$ of total participants (range $=55 \%-100 \% ; S D=14$ ). An average of $14 \%$ Black $(S D=6.7), 7.1 \%$ Latinx $(S D=4.7), 5.4 \%$ Asian $(S D=2.3)$, and less than $5 \%$ each of multiracial, Arab, and Native American respondents were included across the samples. Of studies reporting gender $(n=44)$, women accounted for an average of $68 \%$ of total participants (range $=33-100 ; S D=14.7)$, and men accounted for $31 \%$ of total samples (range $=12-67 ; S D=14$ ). The age of participants, reported in $71.7 \%$ of the empirical studies, ranged from 16 to $81(M=29, S D=8.2)$.

Of the 61 independent samples across the articles, a majority focused on student populations, with master's trainees $(n=20,32.8 \%)$, undergraduate students $(n=14,21.9 \%)$, and doctoral trainees $(n=10$, $16.4 \%)$ representing over $70 \%$ of the sample. The remainder of the samples included practitioners $(n=8$, $13.1 \%)$, unspecified samples $(n=3,4.9 \%)$, university educators $(n=2,3.3 \%)$, educational specialist trainees $(n=2,3.3 \%)$, site supervisors $(n=1,1.6 \%)$, and general population adult samples $(n=1,1.6 \%)$. The target audience of the articles $(N=63)$ focused primarily on counselor trainees $(n=34,49.3 \%)$ or clients in agency/practice settings $(n=12,17.4 \%)$. Other audiences included practitioners $(n=9,13 \%)$, researchers $(n=3,4.3 \%)$, general population $(n=6,8.7 \%)$, counselor educators $(n=1,1.4 \%)$, and general university personnel $(n=1,1.4 \%)$.

\section{Research Design and Data Sources}

Of the 38 quantitative articles, 10 (26.3\%) included an intervention as part of the research design. The majority employed a correlational design $(n=27,71.1 \%)$, with the remainder consisting of four $(10.5 \%)$ descriptive, four (10.5\%) quasi-experimental, one (2.6\%) ex post facto/causal comparative, one $(2.6 \%)$ pre-experimental, and one (2.6\%) true experimental design. In recruiting and selecting samples, most researchers used convenience sampling $(n=27,57.4 \%)$, while the rest used purposive $(n=12,31.6 \%)$, simple random $(n=5,10.6 \%)$, stratified $(n=2,4.3 \%)$, and homogenous $(n=1,2.1 \%)$ sampling methods.

Regarding study instrumentation, 37 quantitative studies utilized self-report forced-choice surveys, with one study employing a combination of forced-choice and open-ended question surveys. Across the 38 quantitative studies, 13 of 50 (26\%) assessments were used more than once. The most frequently used assessment was the White Racial Identity Attitudes Scale ( $n=24$; Helms \& Carter, 1990). The 50 assessments purported to measure the following targeted variables: race/racial identity/racism $(n=17$, $34 \%)$; MCC $(n=9,18 \%)$; cultural identity $(n=6,12 \%)$; counseling process and outcome $(n=5,10 \%)$; social desirability $(n=2,4 \%)$; and other variables such as personality, anxiety, and ego development $(n=11$, $22 \%)$. Finally, data analysis procedures included ANOVA/MANOVA $(n=25,30.9 \%)$, correlation $(n=23$, $28.4 \%)$, regression $(n=17,21 \%)$, t-tests $(n=7,8.6 \%)$, descriptive $(n=5,6.2 \%)$, exploratory factor analysis $(n=1,1.2 \%)$, confirmatory factor analysis $(n=1,1.2 \%), S E M / p a t h$ analysis $(n=1,1.2 \%)$, and cluster analysis $(n=1,1.2 \%)$.

We identified the research traditions of the eight qualitative studies as follows: phenomenology $(n=3,37.5 \%)$, grounded theory $(n=2,25 \%)$, and naturalistic inquiry $(n=1,12.5 \%)$; two were unspecified (25\%). The most common qualitative recruitment method was criterion sampling $(n=5$, $62.5 \%)$, followed by convenience $(n=3,37.5 \%)$, homogenous $(n=2,25 \%)$, snowball/chain $(n=2,25 \%)$, intensity $(n=2,25 \%)$, and stratified purposeful $(n=1,12.5 \%)$ sampling procedures. (Several studies used multiple recruitment methods, resulting in totals greater than $100 \%$.) There were 12 data sources reported across the eight qualitative studies, falling into the following categories: individual interviews $(n=7,58.3 \%)$, focus group interviews $(n=2,16.7 \%)$, artifacts/documents $(n=2,16.7 \%)$, and observations $(n=1,8.3 \%)$. Trustworthiness strategies included prolonged engagement $(n=7,13.7 \%)$; use of a 
research team $(n=6,11.8 \%)$; researcher reflexivity, triangulation of data sources, thick description, and simultaneous data collection and analysis $(n=5$ each, $9.8 \%)$; peer debriefing, audit trail, and member checking ( $n=4$ each, $7.8 \%)$; theory development $(n=3,5.9 \%)$; and one each $(2 \%)$ of external auditor, memos and/or field notes, and persistent observation.

\section{Limitations Within Sampled Studies}

Of the 46 empirical studies, $44(95.7 \%)$ reported limitations. Limitations included design issues related to sampling/generalizability $(n=38,82.6 \%)$; self-report/social desirability $(n=23,50.0 \%)$; instrumentation $(n=20,43.5 \%)$; research design concerns related to the ability to directly measure a variable of interest (e.g., clinical work, training activities; $n=7,15.2 \%$ ); experimenter/researcher effects ( $n=3,6.5 \%)$; use of less sophisticated statistical methods ( $n=3,6.5 \%)$; and use of an analogue design $(n=2,4.3 \%)$. Within identified limitations, researchers most often cited limited generalizability with regard to sample composition (i.e., lack of diversity, small sample sizes, homogenous samples). Social desirability was noted as a potential limitation given the nature of the topics (i.e., racism, prejudice, privilege). Instrumentation issues pertained to weak reliability for samples, limited validity evidence, and disadvantages of self-administration. Researchers also acknowledged the difficulty of conceptualizing WRI constructs as distinct, noting the multidimensional nature of WRI and the challenge in discriminating between complex constructs.

\section{Key Findings}

There were three main categories of key findings. The largest category (i.e., 51 codes) consisted of identification of correlates and predictors of Whiteness/White racial identity. Findings related to gender and WRI were mixed, with several articles $(n=7)$ noting differences in WRI stages among men and women (i.e., women more frequently endorsing Contact and Pseudo-Independent stages, men more frequently endorsing Disintegration and Reintegration), and others determining gender differences were not significant in predicting WRI $(n=2)$. Additional findings included significant positive correlations and predictive effects between WRI, racism, MCC, personality variables (i.e., Openness linked with higher WRI and Neuroticism linked with lower WRI), and working alliance. Other constructs, such as ego defenses, emotional states, social-cognitive maturity, fear, and religious orientation, also demonstrated significant alignment with WRI stages. White guilt, the impact of personal relationships with communities of color, and lower levels of race salience (i.e., race essentialism) were also linked to Whiteness.

The next largest category (i.e., 32 codes) related to critiques of White racial identity models and measures. Most of the conceptual articles focused in some way on this category, often criticizing WRI models as subjective and lacking in complexity, or critiquing WRI measurement and previous research because of issues of reliability and validity. Several stressed caution for interpreting WRI according to existing models, suggesting a more nuanced approach of contextualizing individuals and accounting for within-group variation. Empirical articles also suggested that achieving and maintaining higher levels of WRI, particularly anti-racist identities and attitudes, may be more difficult than originally conceptualized and may require levels of engagement that are difficult to maintain in a racist society.

Training implications and impact (i.e., 24 codes), noted within empirical and conceptual studies, included tips for addressing Whiteness in counselor education (e.g., offering courses focused on Whiteness and anti-racism) and in supervision (e.g., openly discussing race, privilege, and oppression; matching supervisors and supervisees by racial identity when possible). Empirical studies noted mixed improvement in WRI stages and MCC as a result of both general progression 
through a counselor training program as well as specific multicultural training: Training was linked to increased White guilt and privilege awareness $(n=15)$, though others did not find significant effects of training $(n=2)$. Conceptual articles emphasized focusing training on anti-racist development. Collectively, these findings and subsequent implications encourage further research and reflection on the correlates of WRI and MCC, factors facilitating growth, and ways to improve research and measurement to enhance critical engagement with these topics.

\section{Discussion and Implications}

In this content analysis of 63 articles covering a 35-year period across eight national counseling journals, we found that a third of counseling journals featured scholarship specifically related to Whiteness, with the Journal of Counseling \& Development and the Journal of Multicultural Counseling and Development accounting for more than $76 \%$ of the total sampling units. The majority of the articles were quantitative, followed by theoretical and qualitative articles. Topical focus was centered on correlates of Whiteness with variables such as racism and color-blindness, other nonracial components of cultural identity, training implications, and theory development (see Table 3). Interestingly, many Whiteness constructs discussed in the general literature (e.g., White fragility, modern racism, psychosocial costs) were not addressed in counseling scholarship; the primary constructs discussed were WRI and White privilege.

The sample composition across empirical studies was primarily White and female with a mean age in the late 20 s and with undergraduate students comprising on average $22 \%$ of the article samples. In addition, practitioners, site supervisors, the general population, and EdS trainees only comprised between $1.6 \%$ and $13.1 \%$ of the samples. Schooley et al. (2019) cautioned against the overuse of undergraduate students when measuring Whiteness constructs because of the complexities and situational influences of WRI development, and this warning seems to hold relevance for counseling scholarship. Methodological selection mirrored previously found patterns in counseling research (Wester et al., 2013), with most quantitative studies relying upon convenience sampling and correlational design with ANOVA/MANOVA as the selected statistical analyses. In addition, 26.3\% of the articles included an intervention. For the qualitative studies, the most frequently used tradition and method was phenomenology and individual interviews.

Overall, findings from the sample support theoretically consistent relationships with Whiteness and/ or WRI, including their predictive nature of MCC, social desirability, working alliance, and lower race salience. However, findings were mixed on the role of gender and MCC in connection to a training intervention. Additionally, some studies in our sample critiqued WRI models, cautioning against oversimplification of a complex model and highlighting issues in measurement due to subjectivity and social desirability. This critique aligns with previous researchers who have suggested that WRI is more complex than previously indicated (see Helms, 1984, 1990, 2017). WRI may be highly situational and affected by within-group differences and internal and external factors that complicate accuracy in assessment and clinical application. Of particular concern in previous research is the ability to properly conceptualize and measure the Contact and Autonomy stages (Carter et al., 2004). Both stages have demonstrated difficulty in assessment due to an individual's lack of awareness of personal racism at each stage (Carter et al., 2004; Rowe, 2006). The Autonomy status, in particular, could be impacted by what DiAngelo (2018) referred to as "progressive" or "liberal" Whiteness, in which efforts are more focused on maintaining a positive self-image than engaging with people of color in meaningful ways (Helms, 2017). Therefore, although there are some consistencies and corroborations within counseling literature and other scholarship on Whiteness, the critiques and complexities of the topic suggest further inquiry is needed. 


\section{Implications for Counseling Research}

Based on our findings, we note several directions for future research. First, future studies could include greater demographic diversity as well as more participation from counselor educators, site supervisors, practitioners, and clients across the ACES regions. Including counselor educators in empirical studies can highlight aspects of Whiteness that influence their approach to training and scholarship. With regard to increasing scholarship involving site supervisors, practitioners, and clients, Hays et al. (2019) highlighted several strategies for recruiting sites to participate as co-researchers as well as obtaining clinical samples through strengthening research-practice partnerships. Additionally, recruiting more heterogenous samples-in terms of sample composition and demographics - could provide much-needed psychometrics for available measures as well as refined operationalization of Whiteness. Additional research can further explore individual correlates and predictors to enhance counselor training, supervision, and practice by identifying opportunities for assessment and development at each level of WRI.

Second, most reports of empirical studies in our sample noted concerns with sampling and generalizability, social desirability, and instrumentation. Given these concerns, researchers are to be cautious about the interpretation and application of previous study findings using the White Racial Identity Attitudes Scale (WRIAS). In particular, scholarship within counseling and related disciplines reveals substantial psychometric concerns with the WRIAS's Contact and Autonomy stages (Behrens, 1997; Carter et al., 2004; Hays et al., 2008; Malott et al., 2015). The complex nature of assessing WRI-related behaviors that may run counter to a person's intentions (Carter et al., 2004; DiAngelo, 2018) needs further study. Additionally, given the concerns with self-report measures due to socially desirable responses, it seems problematic that none of the current quantitative articles used performance measures, which could help to compare self-report with behaviors and client outcomes. Future research can therefore emphasize behavioral assessments and clinical outcomes to correlate findings with WRI models.

Third, the use of intervention-based research could explore core components of instruction, awareness, and experience to identify facilitative strategies for enhancing WRI in both counselor trainees and within client populations. Because White people are negatively impacted by racism and restricted racial identity, encouraging growth in WRI in both clinical and educational settings can be a means of promoting wellness for counselors and clients. Thus, research is needed that can carefully examine the complexities of WRI development and address difficulties in assessment due to defensive strategies such as White fragility and lack of insight into the various intra- and interpersonal manifestations of racism.

Finally, though the research examined within this analysis advances the application of WRI theory and practices within the counseling profession, opportunities exist for further exploration of WRI development and the intersection with multiple constructs of Whiteness discussed across the helping professions (e.g., White fragility, color-blindness, race essentialism). The articles analyzed for the present study reflect an assumption that more advanced WRI attitudes, lower color-blind attitudes, greater anti-racism attitudes, and greater awareness of White privilege can yield more positive clinical outcomes. However, given some of the aforementioned limitations, this assumption has not been empirically tested in counseling. Because clients' and counselors' affective, cognitive, and behavioral responses to Whiteness can affect the counseling relationship, process, and treatment selection and outcomes (Helms, 1984, 2017), it is imperative that this assumption is properly tested. Empirical and conceptual work should therefore further explore Whiteness constructs to elucidate how White attitudes and behaviors at each stage function for self-protection and move toward aspirational goals of anti-racism and ethical and competent clinical application. 


\section{Implications for Counseling Practice, Training, and Supervision}

In addition to future research directions related to Whiteness and WRI, findings allow for recommendations for counseling practice, training, and supervision. For example, extant literature emphasizes the importance of racial self-awareness, including an understanding of White privilege and racism. The practice of centering discussions on the harmful impacts of Whiteness, as well as the various ways Whiteness can manifest in therapeutic spaces, allows counselors to examine racial development within and around themselves. White counselors who are able to reflect on their own racial privileges and begin the conversation (i.e., broaching) about racial differences can increase the working alliance quality with clients of color (Burkard et al., 1999; Day-Vines et al., 2007; Helms, 1990).

Furthermore, counselors should heed the themes within the key findings of our sample, following recommendations for taking a broad, contextual, and critical view when understanding and applying WRI models. Counselors can be encouraged to view WRI as Helms (2019) intended - as a broad and complex interplay of relational dynamics, connected with other Whiteness constructs, and following an intentional progression toward anti-racism and social justice. Counselors should take particular caution with viewing the Autonomy stage as a point of arrival, given conflicting findings and the possibility that White people in higher stages may engage in behaviors to assuage guilt rather than to be true allies for people of color. The Helms model associates such attitudes and actions with the Pseudo-Independence stage (Helms, 2019), yet findings cast some doubt as to whether White people who score within the Autonomy stage have actually reached that level of WRI development. Counselors should thus interpret assessment scores with caution and ensure they are also assessing their own level of development and subsequent impact on others through continued and honest reflection and positive engagement in crossracial relationships.

Regarding training, course content focusing on exploring Whiteness, WRI, and other racial identities through use of an anti-racism training model integrated throughout the curriculum can help students become comfortable with potential cross-racial conflicts and broaching Whiteness (Malott et al., 2015). The Council for Accreditation of Counseling and Related Educational Programs (CACREP) can similarly stress these desired student outcomes when updating standards for counselor training, specifically mentioning the importance of WRI as part of multicultural preparation. It is imperative to begin conversations about race and identity development to create opportunities for growth for any student who may be challenged with their racial identity and how it might impact their clients. Furthermore, counselor educators and supervisors can ask counselors in training to brainstorm how counseling and other services might be developed or adapted in order to contribute toward anti-racist goals and outcomes.

\section{Limitations}

The current findings are to be interpreted with caution, as the scope of our study presents some limitations. First, we chose to limit inclusion criteria to national peer-reviewed counseling journals in order to focus on scholarship within professional counseling journals, and therefore our results cannot be generalized to similar disciplines, dissertation research, book chapters, or more localized outlets such as state journals. Our coding sheet was also limited in the information it collected, including sample demographics. Though not all studies included the same demographic variables, we did not capture specifics related to a sample's political affiliation, religious orientation, ability status, socioeconomic status, diversity exposure, or other details that could have better conceptualized the samples and findings. Additionally, we limited our search to the keywords related 
to Whiteness that we had identified in related literature but may have missed studies employing constructs outside of our search criteria. Our own identities as White academics may also have influenced the coding process as well as the subsequent interpretation of findings.

\section{Conclusion}

This content analysis provides a snapshot of Whiteness scholarship conducted in the counseling profession during a 35-year period. Patterns of study design and analysis were noted, and key findings were summarized to provide context and comparison within the broader literature. Identified themes and relationships highlight theoretically consistent findings for some Whiteness constructs, as well as showcase research gaps that need to be addressed before counselors can apply findings to practice and training. Finally, this content analysis demonstrates the need for a greater understanding of Whiteness and related constructs in counselor education, training, and practice.

\section{Conflict of Interest and Funding Disclosure}

The authors reported no conflict of interest or funding contributions for the development of this manuscript.

\section{References}

American Counseling Association. (2014). ACA code of ethics.

Behrens, J. T. (1997). Does the White Racial Identity Attitude Scale measure racial identity? Journal of Counseling Psychology, 44(1), 3-12. https://doi.org/10.1037/0022-0167.44.1.3

Burkard, A. W., Ponterotto, J. G., Reynolds, A. L., \& Alfonso, V. C. (1999). White counselor trainees' racial identity and working alliance perceptions. Journal of Counseling \& Development, 77(3), 324-329. https://doi.org/10.1002/j.1556-6676.1999.tb02455.x

Carter, R. T., Helms, J. E., \& Juby, H. L. (2004). The relationship between racism and racial identity for White Americans: A profile analysis. Journal of Multicultural Counseling and Development, 32(1), 2-17. https://doi.org/10.1002/j.2161-1912.2004.tb00357.x

Choney, S. K., \& Behrens, J. T. (1996). Development of the Oklahoma Racial Attitudes Scale Preliminary Form (ORAS-P). Multicultural Assessment in Counseling and Clinical Psychology. https://digitalcommons.unl. edu/burosbookmulticultural/10

Claney, D., \& Parker, W. M. (1989). Assessing White racial consciousness and perceived comfort with Black individuals: A preliminary study. Journal of Counseling $\mathcal{E}$ Development, 67(8), 449-451. https://doi.org/10.1002/j.1556-6676.1989.tb02114.x

Day-Vines, N. L., Wood, S. M., Grothaus, T., Craigen, L., Holman, A., Dotson-Blake, K., \& Douglass, M. J. (2007). Broaching the subjects of race, ethnicity, and culture during the counseling process. Journal of Counseling \& Development, 85(4), 401-409. https://doi.org/10.1002/j.1556-6678.2007.tb00608.x

DiAngelo, R. (2018). White fragility: Why it's so hard for White people to talk about racism. Beacon Press.

Frankenberg, R. (1993). White women, race matters: The social construction of Whiteness. University of Minnesota Press.

Hays, D. G., Bolin, T., \& Chen, C.-C. (2019). Closing the gap: Fostering successful research-practice partnerships in counselor education. Counselor Education and Supervision, 58(4), 278-292. https://doi.org/10.1002/ceas.12157

Hays, D. G., Chang, C. Y., \& Havice, P. (2008). White racial identity statuses as predictors of White privilege awareness. The Journal of Humanistic Counseling, Education and Development, 47(2), 234-246. https://doi.org/10.1002/j.2161-1939.2008.tb00060.x 
Helms, J. E. (1984). Toward a theoretical explanation of the effects of race on counseling: A Black and White model. The Counseling Psychologist, 12(4), 153-165. https://doi.org/10.1177/0011000084124013

Helms, J. E. (Ed.) (1990). Black and White racial identity: Theory, research, and practice. Praeger.

Helms, J. E. (1995). An update of Helms' White and people of color racial identity models. In J. G. Ponterotto, J. M. Casas, L. A. Suzuki, \& C. M. Alexander (Eds.), Handbook of multicultural counseling (1st ed.; pp. 181-196). SAGE.

Helms, J. E. (2017). The challenge of making Whiteness visible: Reactions to four Whiteness articles. The Counseling Psychologist, 45(5), 717-726. https://doi.org/10.1177/0011000017718943

Helms, J. E. (2019). A race is a nice thing to have: A guide to being a White person or understanding the White persons in your life (3rd ed.). Cognella.

Helms, J. E., \& Carter, R. T. (1990). Development of the White Racial Identity Inventory. In J. E. Helms (Ed.), Black and White racial identity: Theory, research, and practice (pp. 67-80). Greenwood Press.

Henry, P. J., \& Sears, D. O. (2002). The Symbolic Racism 2000 Scale. Political Psychology, 23(2), 253-283. https://doi.org/10.1111/0162-895X.00281

LoMartire, R. (2020). Rel: Reliability coefficients. R package version. 1.4.1. https://cran.r-project.org

Malott, K. M., Paone, T. R., Schaefle, S., Cates, J., \& Haizlip, B. (2015). Expanding White racial identity theory: A qualitative investigation of Whites engaged in antiracist action. Journal of Counseling $\mathcal{E}$ Development, 93(3), 333-343. https://doi.org/10.1002/jcad.12031

McConahay, J. B. (1986). Modern racism, ambivalence, and the Modern Racism Scale. In J. F. Dovidio \& S. L. Gaertner (Eds.), Prejudice, discrimination, and racism (pp. 91-125). Academic Press.

McIntosh, P. (1988). White privilege and male privilege: A personal account of coming to see correspondences through work in women's studies (Wellesley College, Center for Research on Women Working Paper, No. 189). Wellesley College. https://www.wcwonline.org/images/pdf/White Privilege and Male Privilege Personal Account-Peggy McIntosh.pdf

Neuendorf, K. A. (2017). The content analysis guidebook (2nd ed.). SAGE.

Neville, H. A., Awad, G. H., Brooks, J. E., Flores, M. P., \& Bleumel, J. (2013). Color-blind racial ideology: Theory, training, and measurement implications in psychology. American Psychologist, 68(6), 455-466. https://doi.org/10.1037/a0033282

Rowe, W. (2006). White racial identity: Science, faith, and pseudoscience. Journal of Multicultural Counseling $\mathcal{E}$ Development, 34(4), 235-243. https://doi.org/10.1002/j.2161-1912.2006.tb00042.x

Schooley, R. C., Debbiesiu, L. L., \& Spanierman, L. B. (2019). Measuring Whiteness: A systematic review of instruments and call to action. The Counseling Psychologist, 47(4), 530-565. https://doi.org/10.1177/0011000019883261

Singh, A. A., \& Shelton, K. (2011). A content analysis of LGBTQ qualitative research in counseling: A ten-year review. Journal of Counseling \& Development, 89(2), 217-226. https://doi.org/10.1002/j.1556-6678.2011.tb00080.x

Spanierman, L. B., \& Heppner, M. J. (2004). Psychosocial Costs of Racism to Whites Scale (PCRW): Construction and initial validation. Journal of Counseling Psychology, 51(2), 249-262. https://doi.org/10.1037/0022-0167.51.2.249

Tawa, J. (2017). The Beliefs About Race Scale (BARS): Dimensions of racial essentialism and their psychometric properties. Cultural Diversity and Ethnic Minority Psychology, 23(4), 516-526. https://doi.org/10.1037/cdp0000151

U.S. Census Bureau. (2020). Public Use Microdata Sample data. https://www.census.gov/programs-surveys/acs/ data/pums.html

Wester, K. L., Borders, L. D., Boul, S., \& Horton, E. (2013). Research quality: Critique of quantitative articles in the Journal of Counseling $\mathcal{E}$ Development. Journal of Counseling $\mathcal{E}$ Development, 91(3), 280-290. https://doi.org/10.1002/j.1556-6676.2013.00096.x 